\title{
A crítica da cultura e a educação estética ${ }^{1}$
}

\author{
Elisabeth Soares da Rocha ${ }^{2}$ \\ Ronaldo Rosas Reis 3
}

\begin{abstract}
Resumo:
A tomada de uma consciência teorética sobre a sensibilidade humana na perspectiva indicada por Marx nos Manuscritos de Paris, se impõe ontologicamente no exame da arte como reflexo do mundo que realmente existe. Com base nesse pressuposto, buscamos na Estética do filósofo húngaro Lukács, assim como nos teóricos marxistas, Gramsci, Eagleton, Jameson, Debord, os elementos para o exercício da crítica da cultura e do caráter social formativo dos sentidos estéticos, manifestamente sobre a criação artística, o conhecimento estético e a produção material sob o sistema capitalista.
\end{abstract}

Palavras-chave: crítica; cultura; ideologia; estética; educação.

\section{The cultural criticism and the aesthetic education}

\section{Abstract:}

The taking of a theoretical consciense about human sensitivity in the perspective indicated by Marx, imposes itself ontologically in the examination of art as a reflection of the world that really exists. Based on this assumption, we sought in the Aesthetics of the philosopher Lukács, as well as in the Marxist theorists, Gramsci, Eagleton, Jameson, Debord, the elements for the exercise of cultural criticism and the formative social character of the aesthetic senses,

${ }^{1} \mathrm{O}$ presente artigo tem por base a tese de doutoramento Estudo crítico sobre as políticas públicas e a formação estético-cultural em Campos dos Goytacazes, defendida por Elisabeth Soares da Rocha, sob orientação de Ronaldo Rosas Reis, no PPG-Educação/UFF (2017).

${ }^{2}$ Doutora em Educação pela Universidade Federal Fluminense (UFF). Professora do Instituto Federal de Educação, Ciência e Tecnologia Fluminense, em Campos dos Goytacazes (IFF-Campos). E-mail: bethrocha12@gmail.com.

3 Doutor em Comunicação e Cultura pela Universidade Federal do Rio de Janeiro (UFRJ). Professor Titular aposentado da Universidade Federal Fluminense (UFF), credenciado do PPG-Educação/UFF.E-mail: ronaldorosas.uff@gmail.com. 
manifestly about artistic creation, aesthetic knowledge and material production under the capitalist system.

Keywords: critique; culture; ideology; aesthetic; education.

\title{
Introdução
}

Se a centralidade do trabalho é, desde o ponto de vista da ontologia crítica, determinante para compreendermos o processo de humanização do homem, certo é igualmente que a contínua exploração do trabalho humano pelo próprio homem se tornou o dilema central desse processo, porquanto historicamente amparado ideologicamente pela construção de uma cultura anti-humanista empreendida por uma classe hegemônica. Ao atribuírem ao trabalho a atividade principal pela qual o homem se cria a si mesmo, Marx e Engels reconhecem no caráter ontológico do trabalho a chave para esse dilema que aflige a organização da vida social: a hegemonia ideológica que se manifesta na cultura. Com efeito, no século XIX, refletindo criticamente sobre as ideias pretensamente revolucionárias dos jovens filósofos hegelianos, eles assim escreveram sobre a disputa hegemônica no campo da cultura:

\begin{abstract}
Apesar de suas frases pomposas, que supostamente revolucionam $o$ mundo, os ideólogos da escola jovem hegeliana são os maiores conservadores (...). Esquecem que eles próprios opõem à fraseologia (dos seus oponentes] nada mais que outra fraseologia e que não lutam de maneira alguma contra o mundo que existe realmente ao combaterem unicamente a fraseologia desse mundo (...). Nenhum desses filósofos teve a ideia de se perguntar qual era a ligação entre a filosofia alemã e a realidade alemã, a ligação entre a sua crítica e o meio natural. (MARX; ENGELS, 2002, p. 9)
\end{abstract}

Em Lukács encontramos o principal interlocutor e, certamente, o mais vigoroso defensor da cientificidade da ontologia do ser social assumida na crítica marxiana-engelsiana ao estatuto epistemológico do saber consagrado pela filosofia clássica, ao positivismo e toda sorte de neofiliação a esta corrente filosófica. De acordo com Vaisman e Fortes, “o combate sugerido por Lukács ao predomínio das reflexões lógico-epistemológicas tem, (...) a perspectiva que concilia a posição teórica com a necessidade prática” (2010, p. 20). Para esses estudiosos da obra do filósofo húngaro, "a ontologia recoloca o problema filosófico essencial do ser e do destino do homem" (2010, p. 21).

No Brasil, a despeito da existência hoje de uma quantidade significativa de estudos críticos sobre a relação cultura, arte e sociedade, publicados e debatidos intensamente, é fato que esses estudos, em sua grande maioria, carecem de uma maior aproximação com o campo da estética, em especial aquela orientada pelo rigor analítico da ontologia crítica. É verdade também que, de um modo geral, a produção acadêmica e ensaística brasileira voltada 
para esse campo tem sido descontínua, quase sempre preambular, em sua maioria pouco afeita ao estudo das relações de produção da arte e do valor como expressão hegemônica dessas relações no mundo capitalista4. Tais estudos passam ao largo, portanto, do esforço dedicado a uma compreensão dialética da dinâmica estrutura-superestrutura da vida social tal como ocorre na perspectiva humanista da ontologia crítica.

No sentido contrário a essa condição incipiente, o presente artigo adota como pressuposto a exigência/competência particular de que a crítica da cultura como reflexo do mundo que realmente existe deve ser o ponto de partida para a apreensão do caráter social dos sentidos estéticos, manifestamente sobre a criação artística, o conhecimento estético e a produção material sob o capitalismo. Para tanto, em três seções que esperamos complementares, buscaremos problematizar a cultura e a vida social considerando o papel formador do campo da estética no seu interior. Por fim, numa seção conclusiva, seguindo a ideia debordiana de cultura espetacular, analisamos o dilema contemporâneo em que nos encontramos em face da distopia do tempo presente.

\section{Da crítica da cultura}

Ao resgatar o télos da cultura, em $A$ ideia de cultura, Terry Eagleton (2011) não se detém ao seu significado antropológico, mas busca aprofundar o debate sobre a dialética da natureza e da cultura numa compreensão de que cultura não é unicamente aquilo de que vivemos. Ela também é, em grande medida, aquilo para o que vivemos e assim, compreender seu significado é fundamental para entendermos sua nova função política (EAGLETON, 2011). Antes mesmo disso, em $A$ ideologia da estética (1993), Eagleton, haveria de considerar relevante para a compreensão dos processos materiais pelos quais a produção cultural configurou-se na sociedade burguesa, a discussão da estética como categoria teórica, a partir da sua defesa de que o "estético é inseparável das formas ideológicas dominantes na sociedade”, em suas palavras,

a categoria do estético assume tal importância no pensamento moderno europeu porque falando de arte ela fala dessas outras questões, que se encontram no centro da luta da classe média pela hegemonia política. A construção da noção moderna do estético é assim inseparável da construção das formas ideológicas dominantes

\footnotetext{
4 Por toda parte tem-se antecipadamente que o valor de uma canção, um livro, uma pintura etc. é algo "já cristalizado enquanto criação artística"; isto é, tais artefatos detêm antecipadamente uma particularidade distinta dos demais (MARTINS, 2005, p. 123).
} 
da sociedade de classes moderna, e na verdade, de todo um novo formato da subjetividade apropriado a esta ordem social (EAGLETON, 1993, p. 8).

A contribuição de Eagleton para a compreensão do conceito de cultura é ampliada quando busca em sua etimologia a raiz inglesa coulter, do latim culter5, a origem do significado cultivo: "Nossa palavra para a mais nobre das atividades humanas, assim, é derivada de trabalho e agricultura, colheita e cultivo" (EAGLETON, 2011). Nesse sentido, cultura aproxima-se da expressão natureza, referindo-se àquilo que tem como característica fundamental o fato de ser natural, apontando para o sentido de que a própria natureza produz cultura que transforma a natureza. Dessa forma, os meios culturais que usamos para transformar a natureza são eles próprios, derivados dela, ou seja, a cultura pode ser vista como meio da autorrenovação constante da natureza, em que a natureza mesma produz os meios de sua própria transcendência. Ou seja, se a natureza é sempre de alguma forma cultural, então as culturas são construídas com base no incessante tráfego com a natureza que chamamos trabalho (EAGLETON, 2011).

Sendo considerados seres culturais, também somos parte da natureza que trabalhamos. A este processo de auto moldagem, unem-se ação e passividade, ao mesmo tempo em que nos assemelhamos à natureza, diferimos dela, pois podemos fazer isso a nós mesmos. Assim tem-se naturalmente, a cultura a que pertencemos bem como a ampliação em nós dessa cultura que recebemos. O termo cultura neste viés sugere uma divisão dentro de nós mesmos, entre aquela parte de nós que se cultiva e refina, e aquela que constitui a matéria-prima para este refinamento. Essa natureza da cultura significa tanto o que está a nossa volta como o que está dentro de nós (EAGLETON, 2011). Na ação dessas transformações em que estão presentes os elementos que constituem o universo cultural contido no homem e na natureza, estes, ao agirem entre si produzem novas formas de manifestação de cultura. Pois se o homem se reconhece homem pelo trabalho, e nessa ação entre homem e natureza, o homem, ao transformá-la por meio do trabalho produz tanto objetividade, quanto subjetividade, assim, o trabalho representa a própria constituição do homem social. Ou seja, nesse tráfego em que natureza e homem se transformam pela ação do trabalho, no desenvolvimento desse processo reprodutivo, cada vez menos o homem encontra na natureza de forma pronta estas condições, portanto, elas passam a ser criadas mediante a prática social dos homens.

\section{Relha de arado}

Elisabeth Soares da Rocha 
O trabalho humano como resultado da transformação da natureza visto em Eagleton, aponta de certa forma para a afirmação de Marx quando este considera que o homem é a própria natureza e dela faz parte:

O homem vive da natureza significa: a natureza é o seu corpo, com o qual ele tem que ficar num processo contínuo para não morrer. Que a vida física e mental do homem está interconectada com a natureza não tem outro sentido senão que a natureza está interconectada consigo mesma, pois o homem é uma parte da natureza. (MARX, 2004, p. 84)

Para Marx e Engels (2002) o primeiro pressuposto de toda história humana é, naturalmente, a existência de seres vivos. A principal ação do homem frente aos outros animais está na possibilidade de que agindo sobre a natureza, ele produz seus próprios meios de sobrevivência. Assim, o homem é ao mesmo tempo transformado pelo processo do seu trabalho, atuando sobre a natureza, e esta por sua vez sobre o homem, modificando-se mutuamente, partindo assim, do ser natural, desenvolvendo-se pela práxis, para um ser cada vez mais social. Nesse processo de autoconstrução humana ergue-se uma dupla determinação: uma insuperável base natural e uma constante transformação social desta base natural, ou seja, o ser social que se realiza a partir de relações causais que compõem a natureza e a base de complexos particularmente sociais. Ou, ainda, no que se refere ao homem e sua relação com a natureza por meio do processo do trabalho, encontramos nessa interrelação a sua expressão cultural, na qual trabalho e cultura podem ser considerados intrínsecos a existência humana.

Nessa condição da relação do ser humano com o ambiente que o cerca o modificando de forma a produzir sua própria sobrevivência e reprodução, Harvey declara que:

Somos seres sensoriais em relação metabólica com o mundo que nos cerca. Alteramos esse mundo, e, ao fazê-lo, alteramos a nós mesmos mediante nossas atividades e labores. (...) temos capacidades e potencialidades específicas de nossa espécie, sendo as mais importantes, ao que se diz, a de alterar e adaptar nossas formas de organização social (por exemplo, criar divisões do trabalho, estruturas de classe e instituições), construir uma longa memória histórica por meio da linguagem, acumular conhecimentos e formas de compreender que estão coletivamente à nossa disposição como guias para uma ação futura, refletir acerca do que fizemos e fazemos de maneiras que nos permitam aprender com a experiência (não só a de nós mesmos como a dos outros), e, em virtude de nossas destrezas particulares, construir todo tipo de extensões de nós mesmos (por exemplo, ferramentas, tecnologias, formas organizacionais e sistemas de comunicação) para levar nossas capacidades de ver, ouvir e sentir bem além das limitações fisiológicas que nos são impostas por nossa constituição corporal. (2004, p. 272)

Elisabeth Soares da Rocha Ronaldo Rosas Reis 
O termo cultura de sua derivação de natureza, de trabalho e agricultura, colheita e cultivo, como citamos anteriormente, foi gradativamente transferindo-se de uma denotação inicial como um processo completamente material, para um sentido metaforicamente relacionado as questões do espírito, passando a designar as atividades que configurariam um conceito que abarcaria os aspectos relacionados à imaterialidade, na qual se inserem as expressões artísticas (EAGLETON, 2011).

Com as mudanças históricas que distinguiriam os habitantes urbanos dos habitantes rurais, formou-se uma nova etapa para o conceito de cultura, uma separação, que colocava de um lado uma elite intelectual ou econômica, considerada culta, detentora de um saber, e, por outro lado aqueles que cultivavam a terra como menos capazes de cultivarem a si mesmos, já que impedidos de tempo para o lazer, em virtude do trabalho e a necessidade de sobrevivência, não dispunham de tempo para o cultivo de si mesmos. Essa dicotomia no conceito de cultura separou indivíduos por sua classe social, pelo acesso à informação e conhecimento disponíveis para ele, marcando profunda e definitivamente o modo de produção capitalista:

No linguajar marxista, ela reúne em uma única noção tanto a base como a superestrutura. Talvez por detrás do prazer que se espera que tenhamos diante de pessoas "cultas" se esconda uma memória coletiva de seca e fome. Mas essa mudança semântica é também paradoxal: são os habitantes urbanos que são "cultos", e aqueles que realmente vivem lavrando o solo não o são. Aqueles que cultivam a terra são menos capazes de cultivar a si mesmos. A agricultura não deixa lazer algum para a cultura. (EAGLETON, 2011, p. 10)

Considerando as relações intrínsecas entre trabalho e natureza, o pensador italiano Antonio Gramsci (1999) se debruçaria sobre a ideia da não exclusividade de um grupo social sobre a cultura, destacando inversamente a capacidade criadora de cada indivíduo, seja qual for a atividade desenvolvida, braçal ou intelectual. Para ele, cada grupo social, nascendo no terreno originário de uma função essencial no mundo da produção econômica, cria para si, ao mesmo tempo, de um modo orgânico, uma ou mais camadas de intelectuais que lhe dão homogeneidade e consciência da própria função, não apenas no campo econômico, mas também no social e no político. Cada um desses grupos sociais cumpre um papel na organização econômica, com uma carga cultural que se refere a toda atividade exercida dentro dessas relações de trabalho. No ato de realização desse trabalho, o homem aplica o seu conhecimento para promover a modificação no ambiente chamado natureza. Nesse movimento de transformação, a natureza responde com os elementos que lhe permitem sofrer alteração pela ação do homem, e aquilo que modificará a ação do homem, por exigir deste uma nova forma de pensar sua ação transformadora na natureza. 
A partir da organização cultural da sociedade, Gramsci (1999) ao afirmar que todo homem é filósofo, busca debater sobre a separação entre o trabalho intelectual e trabalho instrumental, pois “o operário ou proletário, por exemplo, não se caracteriza especificamente pelo trabalho instrumental, mas por este trabalho em determinadas condições e em determinadas relações sociais", ou seja:

É preciso, portanto, demonstrar preliminarmente que todos os homens são filósofos, definindo os limites e as características desta filosofia espontânea, peculiar a "todo o mundo", isto é, da filosofia que está contida: 1) na própria linguagem, que é um conjunto de noções e de conceitos determinados e não, simplesmente, de palavras gramaticalmente vazias de conteúdo; 2) no senso comum e no bom senso; 3) na religião popular e, consequentemente, em todo o sistema de crenças, superstições, opiniões, modos de ver e de agir que se manifestam naquilo que geralmente se conhece por folclore. (GRAMSCI, 1999, p. 93)

Gramsci amplia o conceito de cultura ao elaborar uma crítica ao pensamento de que cultura seja privilégio das classes dominantes. Para ele, se é no âmbito da linguagem que o homem manifesta a sua concepção de mundo ou ideologia - e isso inclui toda a diversidade de concepções possíveis - o problema fundamental se torna em reconhecer na vida social o palco das disputas hegemônicas em torno de movimentos culturais onde estejam contidas as concepções de mundo ou ideologias que se pretendem dominantes.

Para o pensador italiano, a descoberta de que uma multidão de homens seja conduzida a pensar coerentemente de maneira unitária a realidade presente é bem mais original do que a descoberta de uma nova verdade pertencente a pequenos grupos intelectuais. Nesse sentido, de acordo com Gramsci, criar uma nova cultura não significa apenas fazer individualmente descobertas originais; significa também, sobretudo, difundir criticamente verdades já descobertas, socializá-las por assim dizer, e, portanto, transformálas em base de ações vitais, em elemento de coordenação e de ordem intelectual e moral (GRAMSCI, 1999).

A partir desses pressupostos que Gramsci irá reafirmar que todos os homens são filósofos, ainda que a seu modo, inconscientemente, já que, até mesmo na mais simples manifestação de uma atividade intelectual qualquer, na linguagem, está contida uma determinada concepção do mundo, ele aponta para um segundo momento, por ele chamado de momento da crítica e da consciência. Porém, o próprio Gramsci coloca uma questão sobre se

é preferível "pensar" sem disto ter consciência crítica, de uma maneira desagregada e ocasional, isto é, "participar" de uma concepção do mundo "imposta" mecanicamente pelo ambiente exterior, ou seja, por um dos muitos grupos sociais nos quais todos estão automaticamente envolvidos desde sua entrada no mundo consciente (e que pode ser a própria aldeia ou a província, pode se

Elisabeth Soares da Rocha Ronaldo Rosas Reis 
originar na paroquia e na "atividade intelectual" do vigário ou do velho patriarca, cuja "sabedoria" dita leis, na mulher que herdou a sabedoria das bruxas ou no pequeno intelectual avinagrado pela própria estupidez e pela impotência para a ação), ou é preferível elaborar a própria concepção do mundo de uma maneira consciente e crítica e, portanto, em ligação com este trabalho do próprio cérebro, escolher a própria esfera de atividade, participar ativamente na produção da história do mundo, ser o guia de si mesmo e não mais aceitar do exterior, passiva e servilmente, a marca da própria personalidade? (GRAMSCI, 1999, pp. 93-4, grifo nosso).

Para ele, porém, é necessário que se considere que não é possível ser filósofo, ou seja, ter uma concepção de mundo criticamente coerente, sem a consciência da própria historicidade, assim como, ter conhecimento das fases de desenvolvimento que esta consciência representa, e que a coloca em contradição com as demais concepções, ou com os elementos destas concepções. Assim, essa própria concepção de mundo, responde aos problemas impostos pela realidade, que são ao mesmo tempo determinados e originados em sua atualidade.

O sentido de ser filósofo, em Gramsci, passa, portanto, por um processo de construção que busca tornar possível a elevação do senso comum para o bom senso, num sentido em que uma filosofia da práxis só pode apresentar-se, inicialmente, em atitude crítica, como superação da maneira de pensar precedente e do pensamento concreto existente (ou no mundo cultural existente). Já que para ele, neste sentido, não se pode separar a filosofia da história da filosofia, da mesma forma que não se pode separar a cultura da história da cultura. Assim, Gramsci reforça o sentido histórico da cultura, colocando-a num patamar de possibilidade tal qual a elevação do homem à condição de filósofo que lhe é possível ao transpor-se do senso comum à consciência filosófica, analogamente, o homem pode ascender da cultura para a crítica cultural.

Gramsci, ainda reforça a necessidade de concentrarmos forças racionais na busca por uma concepção que forneça um sentido consciente, que precisa ser desenvolvido e transformado em algo unitário e coerente, e aponta para a impossibilidade de separação entre uma filosofia científica e a filosofia vulgar e popular,

Mas, nesse ponto, coloca-se o problema fundamental de toda concepção do mundo, de toda filosofia que se transformou em um movimento cultural, em uma "religião", em uma "fé", ou seja, que produziu uma atividade prática e uma vontade nas quais ela esteja contida como "pressuposto" teórica implícita (uma "ideologia", pode-se dizer, desde que se dê ao termo "ideologia" o significado mais alto de uma concepção do mundo, que se manifesta implicitamente na arte, no direito, na atividade econômica, em todas as manifestações de vida individuais e coletivas) - isto é, o

Elisabeth Soares da Rocha Ronaldo Rosas Reis 
problema de conservar a unidade ideológica em todo o bloco social que está cimentado e unificado justamente por aquela determinada ideologia. (GRAMSCI, 1999, pp. 98-9)

Para que haja um avanço neste processo da compreensão crítica de si mesmo, Gramsci aponta para alguns procedimentos primordiais a serem considerados, os quais perpassam por uma luta de hegemonias políticas, primeiramente no campo da ética, seguido pelo campo da política, a fim de atingir uma elaboração superior da própria concepção do real. Pois, não se pode separar a filosofia da política, antes, deve-se demonstrar que a escolha crítica de uma concepção de mundo, são, também elas, fatos políticos (GRAMSCI, 1999).

Assim, a consciência política é a primeira fase de uma autoconsciência onde teoria e prática se unificam, não de uma forma mecânica, mas como consequência de um devir histórico que gradativamente progride dentro das lutas hegemônicas no processo de distinção e de separação, e progride até a aquisição real e completa de uma concepção de mundo. Então, o processo para tal condição filosófica dá-se nesse desenvolvimento político que o conceito de hegemonia representa, e supõe necessariamente uma unidade intelectual e uma ética adequada à uma concepção do real que superou o senso comum e tornou-se crítica (GRAMSCI, 1999).

Nos processos para alcançar essa visão crítica de mundo, Gramsci chama a atenção para a necessidade de aprofundarmos sobre um estudo que possibilite o conhecimento de como se dá a estrutura ideológica de uma classe dominante, ou seja, a organização material voltada para a manutenção, defesa e desenvolvimento a "frente teórica ou ideológica". Nessa estrutura ideológica, a impressa é considerada a mais dinâmica, mas não a única, pois tudo que pode exercer influência sobre a opinião pública, ainda que direta ou indiretamente, faz parte dessa estrutura. Assim, pode-se considerar como aparelho originário desta influência tanto as bibliotecas, as escolas, os círculos, os clubes, até a arquitetura, quanto à disposição e os nomes das ruas (GRAMSCI, 2001).

Ou seja, a relação entre cultura e ideologia tendo como base o conceito de hegemonia apresentado por Gramsci, entendendo-a como processo no qual uma classe dominante tem sua visão de mundo imposta e aceita pelos indivíduos por ela dominados, faz uso para tanto, dos aparelhos de hegemonia que podem ser instituições de estado, mas também os não oficiais como livros, filmes etc. Portanto a relação entre cultura e ideologia precisa ser considerada como base para a compreensão do processo de dominação nas sociedades capitalistas (GRAMSCI, 2001).

Gramsci ainda considera que não seja possível aceitar uma população totalmente imersa em uma neblina ideológica homogênea e paralisante, pois mesmo na condição de dominado, ele acredita que não seja possível ao homem uma cegueira totalizante que o torne incapaz de pensar criticamente, de se 
debelar, de se mobilizar e assim lutar por alternativas. Isto é, mesmo na consciência dos oprimidos, há uma complexa combinação contraditória de valores, resultante tanto da visão de seus governantes quanto, em alguma medida, derivado do próprio saber e suas experiências políticas e sociais.

Na teoria política de Gramsci, portanto, ideologia, não pode advir de um conceito unissonante, mas complexo, pois ao mesmo tempo que pode ser retratado como recurso que mascara a realidade, pode surgir como capaz de cimentar a constituição de subjetividades políticas. Assim, se a ideologia não constitui um reflexo das estruturas materiais por ter uma autonomia relativa, ela também não poder ser uma simples criação da imaginação ilusória e deformada das pessoas, uma vez que é um fato real e histórico. Nesse sentido, Gramsci é enfático em ressaltar que é por meio da ideologia que as camadas da população podem adquirir consciência crítica na direção da transformação social (SEMERARO, 2006).

\section{Vida social e cultura}

Em O capital, Marx (2005) explicita que nos processos em que se deram o desenvolvimento da indústria, pode-se observar as transformações entre o que se considera primeira etapa do desenvolvimento da produção capitalista, baseada na cooperação simples do trabalho para o processo de produção dividido em várias operações realizadas por diferentes operários. Ou seja, o período da manufatura que tinha sua produção baseada na divisão de trabalho e na técnica artesanal cedeu lugar a grande indústria mecânica, cujo emprego das máquinas, transformou o operário em seu apêndice trazendo como características, o prolongamento do dia de trabalho, a incorporação de mulheres e crianças, a formação de um exército industrial de reserva e o aumento do proletariado, assim como seu empobrecimento.

Vale relembrar que o capitalismo como sistema que começou com a revolução industrial inglesa tornou-se um fenômeno histórico de alcance mundial durante o século XIX. Aliás, Marx conseguiu fazer a anatomia da economia política desse modo de produção construindo uma teoria geral, exatamente a partir da metade desse século, quando ainda vigiam uma ampla competitividade e o período de laissez-faire na Inglaterra. Pode-se extrair dessa análise os elementos invariantes dessas relações sociais e que estariam presentes em todas as formas de capitalismo existentes até hoje. De acordo com Harvey (2014), são consideradas três as características fundamentais gerais do capitalismo:

1. Na sua própria forma de constituição, o capitalismo é orientado para o crescimento contínuo, pois a acumulação de capital, pedra de toque de todo o sistema, só pode ser garantida com o crescimento ininterrupto dos lucros.

Dessa forma, o capitalismo precisa desse crescimento em forma de valores 
reais, e para alcançar esses objetivos ele precisará romper com todas as barreiras políticas, sociais, geopolíticas ou ecológicas;

2. Esse crescimento inevitável e contínuo está baseado na exploração do trabalho vivo na esfera da produção. Assim, mesmo que o trabalho participe e até receba uma parte desse valor, a base do crescimento para o capitalista está sempre na diferença entre o que o trabalho retém e a totalidade do valor que ele cria. É inexorável para que o capitalismo se perpetue, o controle desse trabalho, tanto na produção, quanto no mercado;

3. Para continuar exercendo esse controle sobre o trabalho e consequentemente o crescimento contínuo dos lucros, o capitalismo precisa estar se renovando o tempo todo, provocando através de mudanças tecnológicas e organizacionais, o aumento crescente da produtividade do trabalho, fonte essencial de criação do valor e para isso continuar ocorrendo é fundamental o envolvimento de um marco regulatório que irá envolver a criação de um aparelho de estado, sistemas políticos de representação, ideologias etc.

No período denominado como modernismo - o termo é controverso, porém inevitável $^{6}$-, segundo o qual a cultura seria reconhecida na longa travessia de aproximadamente século e meio desde fins do século XVIII, os inúmeros ciclos de expansão e crise do capitalismo se fariam acompanhar da emergência e da decadência de uma diversidade exuberante de estilos e manifestações artísticas conforme o interesse peculiar do mercado mundial de arte, do gosto hegemônico da burguesia e, até mesmo, dos empuxos contraculturais singulares encabeçados por artistas e intelectuais burgueses. É importante enfatizarmos que independentemente da forma como a evolução e o esgotamento das linguagens artísticas e os embates teóricos no campo da estética ficaram conhecidos no período, a cultura já tinha sido subsumida pelo valor, deixando como lastro o pressuposto de humanidade como um fim em si. Integrada no processo geral de produção de mercadorias, a cultura e a arte se viram cada vez mais esgotadas levando o homem a uma constante alienação da realidade social e de si mesmo (FISCHER, 2014). Na concepção de Marx (2004), essa alienação, traduzida pela contradição entre realidade e aparência no mundo em que vivemos, é definida por fetichismo. Harvey esclarece que este conceito

se referia a várias máscaras, disfarces e distorções do que realmente acontece ao nosso redor (...). A contradição entre realidade e aparência é, de longe, a contradição mais geral e disseminada que temos de enfrentar quando tentamos resolver as contradições mais

\footnotetext{
6 Para Perry Anderson (1985), a noção de modernismo incorre desde a origem num equívoco conceitual histórico, logo, conforme será abordado, a noção de pósmodernismo seria um duplo equívoco.
} 
específicas do capital. O fetiche entendido dessa maneira não é uma crença absurda, uma simples ilusão ou uma sala de espelhos (apesar de muitas vezes parecer). A questão, na verdade, é que o dinheiro pode ser usado para comprar mercadorias e que podemos viver sem muitas preocupações, a não ser a respeito de quanto dinheiro temos e quanto conseguimos comprar com ele (HARVEY, 2016, p. 19).

A desumanização resultante da fragmentação do homem e de seu mundo, sob a lógica capitalista, encontrou no niilismo o modus faciendi da intelectualidade burguesa rebelde, e a arte iniciou a longa trajetória ao encontro de sua própria morte. Se o mundo burguês industrializado e objetificado havia se tornado estranho aos seus habitantes, escritores, músicos e artistas se puseram em campo para agarrar qualquer coisa que lhes garantissem uma possibilidade de romper com a casca rígida dos objetos. Tal dessocialização e desumanização produziria na evolução dos estilos artísticos no decorrer da história, uma ausência de correspondência às necessidades humanas concretas e um total afastamento das relações sociais (FISCHER, 2014).

A partir da segunda metade do século $\mathrm{XX}$, os recorrentes empuxos observados no interior da cultura acabariam por redesenhar o estatuto teleológico do modernismo conhecido até então. Na ausência de uma denominação que se ajustasse à distopia presente para designar qualquer coisa cultural contida pelo modernismo, desde que o mesmo não o fosse mais, cravou-se provisoriamente um termo indefinido que permaneceria indefinidamente na falta de outro: pós-modernismo ${ }^{7}$. De todo modo, dado que a extraordinária expansão do valor havia globalizado as relações de produção, o poder de estado, as estruturas da própria psique etc., tornando a vida social uma expressão cultural, pouco ou quase nada restou a ser apreendido como original ou simplesmente verdadeiro (JAMESON, 1996). Segundo Harvey (2014), as estruturas das formas culturais do pós-modernismo passam a expressar o sentido do aparecimento de uma sociedade pós-industrial inserida numa nova referência, a qual se abre para uma perspectiva radical de poder no qual:

O capital foi reempoderado em relação ao trabalho pela produção de
desemprego e desindustrialização, imigração, deslocalização e toda
sorte de mudanças tecnológicas e organizacionais (a
subcontratação, por exemplo) (...). As concepções mentais do
mundo foram reformuladas, na medida do possível, com o recurso
aos princípios neoliberais da liberdade individual, necessariamente
incorporados no livre-mercado e livre-comércio. Isso exigiu a
regressão do estado de bem-estar social. (...) Novas formas de nicho

7 Dado o que expusemos na nota anterior, o jogo de palavras que impusemos aqui é proposital e conveniente.

Elisabeth Soares da Rocha

Ronaldo Rosas Reis 
de consumo e estilo de vida individualizados também apareceram de repente, construídos em torno de um estilo pós-moderno de urbanização (a Disneyficação dos centros das cidades e a gentrificação), além do surgimento de movimentos sociais em torno de uma mistura de individualismo egocêntrico, política de identidade, multiculturalismo e preferência sexual. (HARVEY, 2014, p. 110)

Em linhas gerais, o pós-modernismo 8 é destituído de qualquer utopia (política, artística, pessoal, etc.), e se constitui de um processo acelerado de coisificação em que questões como a essência e a verdade cederam lugar apenas à aparência das coisas. Num amplo sentido pode-se dizer que é o processo de abandono radical da natureza enquanto algo que se opõe à humanidade, sendo o mundo natural encarado como uma extensão da cultura, na qual subjaz a lógica da rentabilidade. Sobre o processo de coisificação das relações sociais daí decorrente, Sennett, em sua obra $A$ cultura do novo capitalismo (2006), aponta para uma reflexão sobre as relações sociais dentro do processo de fragmentação inerente às relações de trabalho estabelecidas nesse novo capitalismo. Nesse sentido, o sociólogo realiza uma abordagem a partir do momento histórico vivido na década de 60 , em que, jovens imbuídos de ideais libertários, tomavam como alvo as instituições como, as grandes corporações e os governos inflados, os quais, dado seu tamanho, sua complexidade e rigidez pareciam prender os indivíduos num tenaz de ferro. Os insurgentes dessa juventude acreditavam que desmontando as instituições seriam capazes de gerar comunidades com relações pessoais diretas de confiança e solidariedade, constantemente renovadas por novas negociações que proporcionassem um reino comunitário com pessoas sensíveis às necessidades uma das outras. O que se viu, no entanto, foi uma fragmentação das grandes instituições deixando em estado dilacerado a vida de muitos indivíduos, cujos locais de trabalhos se assemelhavam com o ir e vir de uma estação de metrô, com a vida familiar sob desorientação pelas exigências do trabalho, a migração como ícone da era globalizada. Ou seja, o desmantelamento das instituições, não gerou maior senso comunitário, ao contrário, essas novas instituições em condições sociais instáveis e fragmentárias contribuíram para relações de curto prazo, onde a migração de um trabalho e/ou uma tarefa para outra com tamanha velocidade, obriga o indivíduo a improvisar a narrativa de sua própria vida, ao mesmo tempo em que a exigência pelo desenvolvimento de novas capacidades potenciais, tornase inevitável diante das demandas contidas nessa nova realidade. Como resultado, tem-se assim, um indivíduo voltado para o curto prazo, preocupado

8 Ver nota 6.

Elisabeth Soares da Rocha

Ronaldo Rosas Reis 
com as habilidades potenciais e disposto a abrir mão das experiências passadas em busca sempre do novo (SENNET, 2006).

Essa instabilidade visível, inerente ao modelo capitalista, que se apresenta nas turbulências dos mercados, na dança apressada dos consumidores, no vale tudo pela ascensão social, no colapso e transferência das fábricas, na migração em massa de trabalhadores em busca de melhores ou algum emprego, constituíram um processo que desencadeou numa economia de disseminação global da produção, do mercado, das finanças e do advento das novas tecnologias, numa forte e inevitável incerteza:

As pessoas que tenho entrevistado, especialmente na última década, mostram-se demasiado preocupadas e inquietas, muito pouco resignadas com seu próprio destino incerto sob a égide da mudança. O que mais precisam é de uma âncora mental e emocional; precisam de valores que as ajudem a entender se as mudanças no trabalho, nos privilégios e no poder valem a pena. Precisam, em suma, de uma cultura. (SENNET, 2006, p. 168)

Não obstante o debate sobre o lugar da cultura nas relações sociais de produção estar rendido à pressão do mercado global, sendo apresentado como capaz de homogeneizar o planeta, na realidade as diferenças locais estão sendo aprofundadas (SANTOS, 2012). Para Santos, o culto ao consumo é estimulado mediante a busca por uma estandardização, a serviço de marcas mundiais, distanciando ainda mais da construção de uma perspectiva cidadã, ou seja, esse processo, da forma como está configurado, transforma o consumo em ideologia de vida, fazendo de cidadãos meros consumidores, massificando e padronizando a cultura e concentrando a riqueza nas mãos de poucos. Em suas palavras:

Um mercado avassalador dito global é apresentado como capaz de homogeneizar o planeta quando, na verdade, as diferenças locais são aprofundadas. Há uma busca por uniformidade, ao serviço dos atores hegemônicos, mas o mundo se torna menos unido, tornando mais distante o sonho de uma cidadania verdadeiramente universal. Enquanto isso, o culto ao consumo é estimulado. (SANTOS, 2012, p. 19)

Sobre essa cultura globalizada, colocada por Santos, o economista e filósofo francês, Latouche (1996), reconhece a cultura ocidental, como sendo "a única cultura que verdadeiramente se mundializou, com uma força, uma profundidade e uma rapidez jamais vistas, (...) a única cultura dominante que não consegue assimilar seus próprios membros". A partir do desenvolvimento tecnológico do ocidente e da força com que a academia projetou seus pensadores, artistas, filósofos, cientistas, a cultura ocidental assumiu poderes simbólicos de uma dominação insidiosa, na qual novos agentes repousam sobre essa dominação cultural: ciência, técnica, economia e o imaginário, como valores do progresso. Nesses termos, Latouche considera ainda que 
a relação entre Cultura de elite e a dominação da cultura ocidental está no fato de terem transformado os fluxos culturais em "mão única", de onde projetam para as demais partes do mundo através dos meios de comunicação (jornais, rádios, televisões, filmes, livros, discos, vídeos), imagens, palavras, valores morais, normas jurídicas e códigos políticos que informam aos seus receptores os seus desejos e necessidades, as formas de comportamento, as mentalidades, os sistemas de educação que devem ter, porém asfixiando toda criatividade dos receptores passivos de tais mensagens (LATOUCHE, 1996, p. 16).

Segundo Reis, os meios de comunicação cuja veiculação realiza-se "pela extensa cadeia midiática, incluindo meios impressos, TV, rádio, cinema e, principalmente, a Internet com suas redes sociais" (2015, p. 14), mediante suas intensas campanhas publicitárias, tem sido responsáveis pela sedução da população trabalhadora na busca de realização de seus anseios ao ponto de gestos simples como o ato de cozinhar entre família e amigos sejam transformados em refeições "não mais para serem simplesmente sentidos pelo paladar, mas, tão somente para comercializarem uma extraordinária quantidade de produtos, restaurantes e serviços de profissionais da cozinha" (REIS, 2015, p. 14). Reis acrescenta ainda que,

na esfera cultural propriamente falando as produções teatrais, o cinema, as artes plásticas, salvo as exceções de praxe, convergem para o mercado concorrendo com os subprodutos televisivos produzidos pela indústria cultural de massa. Em todas essas circunstâncias a dimensão criativa da atividade humana é simplesmente elidida ou travestida pelo consumo conspícuo de algo fadado à obsolescência. No sentido contrariamente dialético dessa sedução se encontram aqueles que praticarão o terrorismo privado e de estado contra a classe trabalhadora: banqueiros usurários, rentistas, empresários, agentes públicos no controle das economias do estado etc. (2015, pp. 14-5).

Ou seja, a dimensão da criatividade humana travestida pelo consumo conspícuo conforme vimos, transformou a vida em filme, evocando o título da obra Vida, o filme. Como o entretenimento conquistou a realidade, de Neal Gabler (1999), na qual o escritor estadunidense apresenta uma análise sobre como a mídia, por meio da

aplicação deliberada de técnicas teatrais em política, religião, educação, literatura, comércio, guerra, crime, em tudo, converteuos todos em ramos da indústria do entretenimento, na qual o objetivo supremo é ganhar e satisfazer uma audiência (REIS, 2015, p. 16).

Chamando ainda a atenção para o momento em que a cultura se submete à tirania do entretenimento e a vida se torna um filme, os críticos reclamam que os Estados Unidos retrocederam a uma "cultura carnavalesca", ou "cultura do 
lixo", onde tudo é embrutecido, vulgarizado e banalizado, (...) onde os laços comunitários antes forjados por tradições e valores morais comuns são hoje forjados pelas manchetes dos tabloides, por mexericos e pela mídia (REIS, 2015, p. 16).

Designada a partir do latim inter (entre) e tenere (ter), inter tenere, entretenimento significa "um espetáculo público ou mostra destinada a interessar ou divertir", ou nas palavras de Gabler, o entretenimento "enterra suas esporas em nós e nos puxa, mantendo-nos cativos, levando-nos cada vez mais para dentro dele (o entretenimento), e de nós mesmos, ou pelo menos de nossas emoções e sentidos, antes de nos libertar" (REIS, 2015, p. 25).

\section{Estética e educação}

Os sentidos aprisionados de que fala Gabler pertencem a uma categoria complexa e sobretudo importante na literatura marxiana, em especial nos estudos do campo da estética: o estranhamento. Marx a abordou primeiramente em 1844, nos escritos de Paris, no excerto "Trabalho estranhado e propriedade privada" (2004, pp. 79-97), do qual recuperamos de forma sintética a ideia de que sendo o valor a expressão manifesta do capitalismo, e o corpo do trabalhador a materialidade concreta dos sentidos humanos, tem-se que o processo de produção sob o capitalismo é, a um só tempo, o processo de estranhamento do corpo do trabalhador em relação àquilo que ele produz (a cultura humana), e também o processo de subsunção do corpo do trabalhador a uma sensibilidade vicária, uma fantasmagoria. Em outras palavras, Marx aponta que na medida em que o corpo do trabalhador é mantido apenas fisicamente, os seus sentidos - ou se se preferir a sua sensibilidade - se tornam "sem valor e indignos, deformados, bárbaros, impotentes, pobres, mais servis à natureza" (2004, p. 82). Nos termos do próprio Marx:

O trabalho produz maravilhas para os ricos, mas produz privações para o trabalhador. Produz palácios, mas produz cavernas para o trabalhador. Produz beleza, mas deformação para o trabalhador. Substitui o trabalho por máquinas, mas lança uma parte dos trabalhadores de volta a um trabalho bárbaro e faz da outra parte máquinas. Produz espírito, mas produz imbecilidade, cretinismo para o trabalhador. (2004, p. 82)

Ora, se em sua origem natural o homem é provido de sentidos mediante os quais ele é capaz, contrariamente aos animais, de "reproduzir a natureza inteira" (2004), temos que na condição concreta ora examinada o homem "não se sente bem", é infeliz posto que sua physis se encontra mortificada e seu espírito arruinado (2004, pp. 82-3). Estranhados do mundo dos objetos que produz e que o cerca (a cultura), destituídos de liberdade criativa, os sentidos 
do corpo do trabalhador se encontram limitados quanto à fruição das leis $d a$ beleza (MARX, 2004).

Para Marx, a verdadeira ciência é aquela que começa pela natureza, logo, sendo a percepção sensível "uma forma dupla de consciência sensível e necessidade dos sentidos", será ela a base de todo conhecimento científico. Portanto, ao considerar a sensibilidade como um elemento fundador do próprio corpo, e assim, inaugurador de todo o conhecimento, Marx aponta não apenas para uma reabilitação da percepção sensível ou sensorial, mas também para uma revalorização do conhecimento artístico. De acordo com Marx,

os sentidos do homem social são diferentes dos do homem que não vive em sociedade. Só pelo desenvolvimento objetivo da riqueza do ser humano é que a riqueza dos sentidos humanos subjetivos, que um ouvido musical, um olho sensível à beleza das formas, que numa palavra, os sentidos capazes de prazeres humanos se transformam em sentidos que se manifestam como forças do ser humano e são, quer desenvolvidos, quer produzidos. (...) A formação dos cinco sentidos representa o trabalho de toda a história do mundo até hoje (MARX, 2004, p. 110).

Ao considerarmos, no entanto, a relação do corpo humano numa sociedade que passou a se apresentar sob a perspectiva do sistema capital e seu avanço tecnológico, na qual as relações de trabalho, transformaram o corpo sensível num impulso único de possuir, encontramos, assim, os sentidos físicos e intelectuais substituídos pela simples alienação de todos - no sentido de ter. Ou seja, a lógica do capitalismo reduz a plenitude corpórea de homens e mulheres à simplicidade crua e abstrata da necessidade, porque quando a mera sobrevivência material está em jogo, as qualidades sensíveis dos objetos intencionados por essas necessidades não se tematizam. Sobre esse aspecto, Reis (2004) chama a atenção para a forma com a qual Marx, ao apreender a maneira em que o mundo construído se apresenta, desde as formações sociais primitivas às mais complexas, o apresenta por meio de uma "metáfora materializada do corpo trabalhador", no qual, todo o sistema de produção econômica constitui o elemento que age sobre o processo de "descorporificação e espiritualização de homens e mulheres". Ainda acrescenta que:

Na medida em que a plenitude sensível do indivíduo é reduzida ao impulso único de possuir, isto é, na medida em que a plenitude corpórea de homens e mulheres é reduzida ao simples ato de suprir as suas necessidades elementares, faz sentido afirmar a ocorrência, nesse nível, de uma ruptura da vida sensível. (REIS, 2004, p. 233)

Ou seja, por um lado, temos o trabalhador devastado pela necessidade, sem tempo para usufruir da arte, cultura, lazer, por outro lado, o desocupado das classes altas, alienado da vida sensível, percebe-se um aleijão que, pela ausência de necessidade, desenvolve desejo pelas circunstâncias materiais que se torna perversamente auto produtivo, representando apetites refinados, 
antinaturais e imaginários que crescem luxuriosamente em suas extremas sutilezas. Isto é, não é a apropriação de um objeto pelo uso que corrói a sua sensibilidade, mas a submissão do objeto ao valor e à consequente desumanização da sua necessidade de fruição ${ }^{9}$.

Sob esse aspecto, Lukács aponta para a possibilidade de um processo desfetichizador da obra de arte como um meio de recuperar a percepção sensível do corpo do trabalhador. Para ele, a criação artística deve partir de um processo social geral e organicamente articulado no qual o homem torna seu, o mundo por meio da própria consciência. Nesse sentido, o crítico tanto quanto o artista ao aspirarem à objetividade do realismo, é necessário que o façam como resultado da "complexa dialética objetiva de essência e fenômeno, (...) na inter-relação que liga sempre o escritor à realidade refletida, sua relação de influência recíproca com a concepção de mundo e o estilo artístico" (OLDRINI, 2002, p. 58).

Dessa forma, a realidade objetiva implica, portanto, na não neutralidade mediante os fenômenos sociais pois, tal objetividade não se acha contraditoriamente em relação ao fator subjetivo da arte. E sim, no sentido de totalidade, onde o artista não representa coisas ou situações estáticas, mas as investiga, buscando conhecer e definir o caráter dentro das relações dos processos sociais. Ou seja, numa tomada de consciência, já está implícita a tomada de posição, já que a concepção de que o artista seria um espectador passivo desses processos, é uma ilusão, uma forma de autoengano, ou ainda, uma evasão, uma fuga diante dos grandes problemas da vida e da arte. Oldrini acrescenta a este debate que a obra de arte para Lukács deve ser compreendida como uma necessidade interna da nova teoria que está sendo construída exatamente pelo fato de que, melhor do que qualquer outra tendência artística, ela traz em si a consciência dialética da "totalidade". Se a "representação" realista vale mais do que a crônica e a reportagem, se o "narrar" vale mais do que o "descrever", é porque quem narra e representa penetra, com meios artísticos, mais profundamente nas "leis dialéticas objetivas" da estrutura do real (OLDRINI, 2002, p. 57).

Temos então contrapostos narração e descrição. Enquanto nesta última se encontra em pé de igualdade a ação humana e as coisas esvaziadas do sentido da vida social, ao contrário disso na narração encontramos um ordenamento hierárquico do enredo, evitando as digressões desnecessárias,

9 A se considerar correto o pressuposto de que "a maneira como os indivíduos manifestam sua vida reflete exatamente o que eles são" (MARX; ENGELS, 2002, p. 11), temos que, nas condições sociais atuais, pobres e ricos compartilham uma existência dialeticamente parasitária, como tão bem ilustrou o cineasta coreano Bong

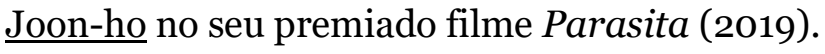


onde os detalhes só são importantes quando se desencadeiam na ação humana, e estão a serviço delas. Ou seja, para Lukács o potencial utópico da arte está na sua capacidade para expressar a essência genérica. A obra de arte é produto de uma subjetividade que transcende a individualidade e seu condicionamento histórico e de classe para configurar e plasmar em sua singularidade, universal e permanente: a memória da humanidade. Esta particularidade da arte para captar os momentos essenciais da história da evolução humana, permite desenvolver nos homens uma autoconsciência sobre sua própria essência genérica. Esta essência genérica capturada através da arte, não está identificada com uma suposta relação com o tempo, mas sim, com a história concreta do homem.

Lukács definirá como categorias indissociáveis do homem, o trabalho, a linguagem, a cooperação e a divisão social do trabalho, entendidas como intrínsecas à sociabilidade humana, que por sua vez originam níveis mais complexos do ser social, constituindo a ideologia, cujas formas mais específicas são o direito, a política, diretamente mais ligadas a práxis social e numa forma mais mediatizada, a filosofia e a arte. Ou seja, tanto a cultura quanto a arte, contrariamente às visões formalistas e elitistas, compreendem uma dimensão humana essencial. Ao fazer referência à arte como pioneira da generidade para si, Lukács chama a atenção para uma arte que seja capaz de produzir uma consciência do indivíduo diante da sua situação particular, o que não significa que a arte infira efeitos diretos na prática cotidiana do receptor, mas que ela seja capaz de produzir uma revelação de novas possibilidades de se compreender no mundo (ALBINATI, 2014, p. 266).

É nesse sentido que a arte pode adquirir a possibilidade de gerar no indivíduo, a sua própria concepção do real, tal como descrito em Gramsci, “a compreensão crítica de si mesmo é obtida, portanto, através de uma luta de hegemonias políticas, de direções contrastantes, primeiro no campo da ética, depois no da política, atingindo, finalmente, uma elaboração superior da própria concepção do real” (GRAMSCI, 1999, p. 103). A partir dessa formulação emerge uma ideia da organicidade entre forma e conteúdo na dimensão estética e sua conexão com as relações entre estrutura e superestrutura. Nesse ponto Gramsci ressalta a dívida da arte em relação à história, pois, é a partir desta que através da atividade revolucionária que poderão ser criados, o novo homem e as novas relações sociais ${ }^{10}$. A concepção

10 Ao formular a sua concepção de arte dentro de uma dimensão estética do fato artístico, o pensador sardo propõe que ela deve representar uma síntese dinâmica entre a forma e o conteúdo, ou seja, a luta por uma nova cultura advinda de um novo humanismo, tendo como fundamento a fusão entre a crítica dos costumes das concepções e sentimentos do mundo e a crítica estética. 
gramsciana de arte fica mais clara ainda quando ele reconhece, de certa forma aproximando-se das concepções de Lukács, que há momentos em que essa relação se inverte e é a arte que faz a história.

Lukács irá defender uma arte a partir do que ele denominou de realismo crítico. Tal conceito não sugere uma escola, nem tampouco um estilo, mas sim, um procedimento com relação a como a realidade se constitui, isto é, historicamente, e não datada. O realismo para Lukács é uma trajetória de autoconhecimento do homem, onde o artista examina e apreende as possibilidades significativas da realidade, tomando posição perante essa realidade que se traduz na seleção e reordenamento dos elementos que compõe a obra de arte. A relação entre criador e receptor, considerando a capacidade comunicativa e evocativa da obra de arte, proporciona possibilidades de auto constituição do humano, elevado a uma consciência crítica da realidade que o cerca, tornando-o capaz de sair do homem inteiro da cotidianidade ao homem inteiramente (ALBINATI, 2014, p. 267). Na sua visão do realismo crítico, Lukács desenvolve uma crítica à arte vanguardista, que já aparecia implícita desde sua obra Teoria do romance, onde apontava para a crise estética presente na modernidade decorrente da decadência do ocidente, em que a literatura do romance, desprovida do caráter imanente e orgânico das Tragédias da Grécia antiga, encontra-se num mundo reificado, no qual o indivíduo perdeu seus laços com a comunidade. O romance, portanto, no qual o herói luta em nome dos valores que a sua época renega, provoca nesse sentido, uma distância entre o mundo objetivo e subjetivo. Ou seja, realismo é um método para reproduzir a realidade e para tanto, pressupõe uma atitude do escritor perante o real. Logo, o realismo vem dos gregos até os dias de hoje, cujo modelo no qual se baseia encontra em Balzac sua melhor expressão, ao mesmo tempo em que Lukács apresenta uma visão matizada, valorizando a atitude perante o real, que se modifica o tempo todo, buscando a cada mudança captar as novas etapas da realidade, tal como se segue.

Um aspecto central considerado por Lukács (1969) é o problema da fetichização da arte na sociedade do valor. Nesse sentido, ele chama a atenção para a necessidade de o artista romper esse invólucro a fim de desvelar o núcleo humano da obra ${ }^{11}$. Outro aspecto importante destacado pelo filósofo húngaro é o reconhecimento, extraído de Hegel, de que a obra de arte é uma manifestação sensível, na qual, aparência e essência, forma e conteúdo estão traduzidas numa unidade. Assim, Lukács enfatizará que não deve haver predomínio de um elemento sobre o outro pois, quando se destaca unilateralmente, a forma ou o conteúdo, a obra de arte fracassa. A ênfase dada

${ }^{11}$ No caso específico da literatura, do romance, isso significa dizer que é necessário colocar em primeiro plano a centralidade da ação, isto é, a ação dos personagens.

Elisabeth Soares da Rocha

Ronaldo Rosas Reis 
à forma pelo naturalismo e ao conteúdo pelo expressionismo, exemplificam respectivamente como o primeiro faz uma descrição da aparência imediata, e o segundo promove uma deformação intencional da forma para tornar visível o conteúdo. Nesse sentido, insistindo na sua crítica ao vanguardismo, Lukács considera que, num primeiro momento, a classe burguesa age de forma revolucionária e progressista, tem interesse em desvendar a realidade, e dentro deste contexto é que aparecem o romance realista, a economia clássica inglesa e a democracia. Tal produção literária, denominada como romance burguês, se apresenta como uma arte que vai tratar os homens como produtos da sociedade e acompanhar a afirmação dessa classe burguesa na história. Porém, com o levante da classe operária contra a burguesia, esse pensamento inicial burguês sofre mudanças, perdendo a dimensão do futuro, portanto, do processo de desenvolvimento da própria história. O romance realista se torna naturalista, a economia clássica vira economia vulgar. Assim, seus interesses se voltam não mais em conhecer como funciona a sociedade, mas para um pensamento manipulador no qual a democracia vai se restringir ao liberalismo e a participação popular é posta de lado.

Essa decadência ideológica da burguesia marcou o fim de um ciclo histórico, a partir do que se modificou também a concepção do capital em relação a arte e o escritor burguês se situou diante de uma mistificação crescente que penetra a consciência do homem e o impede de ver o nexo real que compõe a vida social. Tal situação geraria uma literatura com visões objetivistas que, por um lado, se apegou a aparência do real, e sucumbiu ao conformismo, retratando os resultados finais da deformação capitalista do homem, e por outro lado, os escritores procuraram refúgio na subjetividade da alma, inteiramente autônoma em relação ao mundo. Nesse sentido, Lukács (1965) enfatiza sua crítica ao ressaltar que esses escritores apenas reproduziam a aparência fetichista de um mundo burguês, não acreditando mais na possibilidade do homem de modificar-se. Em suas palavras:

A hostilidade da ordem de produção capitalista à arte se manifesta igualmente na divisão capitalista do trabalho. Um maior desenvolvimento na compreensão desse aspecto do tema nos remeteria, ainda uma vez, ao estudo da economia como uma totalidade. Do ponto de vista do nosso problema, vamos nos contentar em fixar aqui um só princípio, que será, novamente, o princípio do humanismo, o princípio que a luta emancipadora do proletariado herdou dos grandes movimentos democráticos e revolucionários precedentes, herança elevada a um plano qualitativo superior, ou seja, a reinvindicação do desenvolvimento harmônico e integral do homem. Ao contrário, a hostilidade à arte e à cultura, própria do sistema capitalista comporta o fracionamento da totalidade concreta do homem em especializações abstratas. (LUKÁCS, 1965, p. 20)

Elisabeth Soares da Rocha Ronaldo Rosas Reis 
Para Reis, "não seria exagero considerar o romantismo o marco inaugural do sentimento libertário que mais adiante impregnaria os movimentos vanguardistas no século XX” (2015, p. 218), todavia, considerando as sucessivas rupturas estilísticas que ocorreram nos diversos períodos marcados por aqueles movimentos, é necessário enfatizar que elas esbarraram na sua pequena dimensão política e insuficiente inserção social, pois as supostas revoluções artísticas lideradas por esses movimentos, ficaram apenas na aparência, por deixarem de lado a essência das relações sociais.

Nos desdobramentos das reflexões sobre a arte até aqui desenvolvidas, buscaremos sintetizar a visão de Lukács sobre a música, tema do volume quatro da sua Estética (1967). Ali o filósofo propõe examinar a questão da mimese musical, a partir do que buscaremos extrair, alguns elementos a respeito da relação da estética musical com a formação humana.

Lukács dá início ao seu exame da música tendo como referência um extenso e detalhado estudo do professor grego Theophratos Georgeadis acerca da música e do ritmo entre os gregos. Nesse estudo, o filósofo húngaro toma noção de que Aristóteles buscava demonstrar a natureza mimética da música, afirmando que os ritmos e as melodias musicais podem suscitar no ser humano sentimentos que variam de acordo com a combinação desses sons na composição musical, conforme lemos na citação feita por Lukács:

Los ritmos y las melodías se acercan mucho como copias a la esencia verdadera de la cólera y la dulzura, así como del valor y la mesura, y de sus contrarios, junto con la naturaleza peculiar de los demás sentimientos y propiedades éticas. Así lo muestra la experiencia. Oímos tales melodías y cambia nuestro ánimo. Mas no hay mucha distancia entre la costumbre adquirida de entristecerse o alegrarse por lo semejante y el mismo comportamiento respecto de la realidad. (ARISTÓTELES apud LUKÁCS, 1967, p. 9)

Também Chasin (2008) irá buscar em Aristóteles o reconhecimento da música como um ato mimético, como expressão da vida afetiva, interioridade que se exterioriza, subjetividade que sente, onde ritmos e melodias afloram do interior e sensificam sentimentos, que na prática "ao ouvir tais mimeses, a alma muda de estado" (CHASIN, 2008, p. 15). Conforme lemos na citação que faz do filósofo grego, Chasin destaca que:

as peças de música, pelo contrário, contêm atualmente em si mesmas imitações de caracteres, e isto é evidente, pois que na própria natureza das simples melodias há diferenças [recíprocas], de modo que ao ouvi-las as pessoas sentem-se afetadas de diferentes maneiras, e não têm os mesmos sentimentos em relação a cada uma delas; escutam, umas, com um espírito lamurioso e mais retraído, como, por exemplo, o modo chamado mixolídio; outras, num estado suave e brando da mente, como são as melodias livres; outras num estado de equilíbrio e da maior serenidade, como parece que, entre todas, alcançam somente as do modo dórico; enquanto que o modo

Elisabeth Soares da Rocha Ronaldo Rosas Reis 
frígio infunde entusiasmo aos homens. Estas coisas, com efeito, foram bem determinadas pelos que estudaram esta forma de educação, já que eles extraíram a evidência de suas teorias dos fatos atuais da experiência (ARISTÓTELES apud CHASIN, 2008, pp. 14$5)$.

Vemos já aqui introduzida uma preocupação com a tomada de consciência teorética sobre aquilo que os sons manifestam mimeticamente permitindo-nos apreendê-los na forma de melodia ${ }^{12}$. Ou seja, como Lukács assinala, a imitação dos sons da natureza não se dá sem uma consciência teorética, posto que já há um salto entre os sons existentes na natureza e a captação do ouvido humano destes sons até a configuração musical elaborada pelo homem. Citando Herder, Lukács destacará que, "ningún artista ha inventado nunca un sonido ni le ha dado un poder que no tuviera en la naturaliza y en su instrumento; pero sí que lo descubrió, y le obligó con dulce fuerza a salir a la luz" (HERDER apud LUKÁCS 1967, p. 11). Nesse sentido, é fundamental considerar que este processo só foi possível pela evolução social do homem. Isto é, o fato de que o som do instrumento seja determinado por leis naturais ainda que não tenham distinguido de outros produtos do trabalho: a diferença está no propósito dos efeitos alcançados, a partir do fenômeno natural simples:

Pues la concepción de la música como una particular especie de mimesis acentúa enérgicamente con una seguridad dialéctica nada sorprendente en los griegos, aquello que, desde el punto de vista de la mimesis, aparece con la música en el cosmos de las artes, y al mismo tiempo, e inseparablemente, lo que separa a la música de todas las demás artes, lo que constituye su peculiaridad específica. No había duda para los griegos de que toda relación humana con la realidad, la científica igual que la artística, se basa en un reflejo de la naturaleza objetiva de dicha realidad. Las divergencias internas y externas entre la música y las demás artes no pudieron nunca resquebrajar esa convicción de ellos. Por otra parte, los griegos vieron con toda claridad que el objeto miméticamente reproducido por la música se distingue cualitativamente de los de las demás artes: es la vida interior del hombre. (LUKÁCS, 1967, p. 8)

No encontro da música com a realidade considerando o aspecto de seu reflexo, assim como o objeto-sujeito, ela é inexoravelmente parte da interioridade humana, da vida emocional humana. Porém, é preciso considerar que imediatamente e originalmente, esta interioridade não existe

12 A consciência teorética, expressão utilizada originariamente por Marx nos Manuscritos de Paris (2004), detém um por teleológico que é a educação dos sentidos. Isto é, a necessidade de provimento da sensibilidade humana de uma consciência sobre as formas visuais, sonoras, tácteis, palatáveis etc., com a finalidade social de estabelecermos distinções estéticas. 
em todas as esferas como independente da vida humana, mas sim como produto histórico-social da humanidade. Ou seja, a música como resultado da mimese da vida interior, se dá a partir da função que a tem designado todas as circunstâncias históricas e sociais de toda a cultura. Nesse sentido, a tarefa filosófica da arte consiste em descobrir as conexões categóricas que se impõem neste processo, desde que tal função ordenadora da música esteja essencialmente conectada com a sua materialidade histórica (LUKÁCS, 1967). Nestes termos, há de se considerar as questões entre o original e a reconfiguração, isto é, no fato de que a música por um lado se expressa a partir de vibrações que se identificam com precisão matemática, e por outro lado subjetivo, no que se refere a audição e impressões que lhe é inerente como consequência das percepções do homem. Recordando que em Marx, a interioridade do homem presente na sua subjetividade é consequência de sua percepção sensível, não podemos ignorar que nas condições sociais de produção capitalista há de se pensar que sem uma operação facilitadora destes processos de trabalho não será possível obter a liberação da interioridade do homem. Se considerarmos este fenômeno pelo lado subjetivo, vemos que a diminuição do esforço para aumentar o efeito do trabalho traz consigo o início de uma liberação da interioridade, da expansão das sensações que acompanham o trabalho e, portanto, da vida emocional do homem como um todo.

Nesse sentido, Lukács relaciona

la posición del hombre entero respecto del trabajo específico de cada caso, su relación subjetiva con la totalidad del trabajo en su vida, con las condiciones de trabajo, con las relaciones de trabajo en general, como contenido de la mimesis de las impresiones [onde a música configura como] consecuencia necesaria de su esencia estética como refiguración de la totalidad emotiva, o sea, como mimesis de una mimesis (1967, pp. 20; 69).

A música circunscrita a partir da estética defendida por Lukács, afigurase particularmente no que diz respeito ao seu efeito e o seu lugar na vida dos homens. A partir das ideias de Platão e Aristóteles no que se refere ao "significado ético, pedagógico e social da música", Lukács coloca assim a música pelo seu efeito catártico como sendo capaz de produzir no homem um ver-se em um espelho, confirmando a essência de sua própria vida, precisamente porque mostra, fornecida pela mimese estética, essa possibilidade, acima do que normalmente se encontra acessível, a uma consciência sobre as verdadeiras condições humanas. Isto é, por meio da catarse produzida pela música, o homem experimenta a própria realidade da vida humana, em comparação com a realidade da vida cotidiana. A música se distingue, segundo Lukács, das outras artes, bem como a catarse por ela produzida, pelo fato de que não é sobre a interação dos mundos externos e 
internos, provocando a comoção libertadora, que ela se dá. O que significa dizer, que a música pode provocar no homem uma subjetividade tão intensa, capaz de levá-lo a alcançar a sua própria interioridade (LUKÁCS, 1967).

El profundo efecto de la música consiste precisamente en que introduce al receptor en su mundo, le hace vivir en él y vivenciarlo, pero, pese a la penetración más profunda, pese a la más vehemente liberación de las emociones, construye ese mundo siempre como diverso del yo del receptor, como un mundo distinto de él y significativo para él precisamente gracias a esa diversidad específica. La obra de arte musical recibe de fuentes de contenido el carácter de "mundo" para-sí: de la madura totalidad de las emociones que se revelan en ella. Sólo cuando esas emociones son, vistas humanamente, cosa esencial, sólo cuando son capaces de desplegar a su vez hasta las últimas consecuencias, las emociones que ellas mismas desencadenan, sólo entonces puede surgir un "mundo" en el sentido del arte. (LUKÁCS, 1967, p. 81)

Mas nem toda atividade artística produz obras de arte capazes de cumprir esse papel apontado por Lukács, posto que, na sociedade do valor, a profunda alienação em relação a tudo aquilo que o indivíduo supõe hoje ser uma civilização, resulta de uma conta de resultado impossível: quanto mais do mesmo ele acumula para si, mais profunda é a sua ignorância de saber-se prisioneiro do mesmo. É o que procuraremos considerar no exame seguinte a título de conclusão.

\section{Estetização da vida social e a "comunicação do incomunicável"}

Partimos nesse texto da exigência de que a crítica da cultura como reflexo do mundo que realmente existe, deve contemplar o caráter ontológico dos sentidos como forma de apreender "a riqueza objetivamente desdobrada da essência humana” (MARX, 2004, p. 110). Para tanto buscamos até aqui problematizar a cultura e a vida social considerando o papel formador do campo da estética no seu interior. Não por acaso deixamos para o final o exame da correlação entre a música e a consciência teorética na formação do homem singular em busca de um sentido particular para as suas emoções mais profundas. Nele apontamos que numa sociedade na qual a arte é sistematicamente submetida à lógica da sociedade do espetáculo (DEBORD, 2017), decerto que a incapacita de elevar o indivíduo à esfera da particularidade. Como ressalta Lukács, tal condição contemporânea, impõe ao indivíduo uma solidão ontológica peculiar (1969), empurrando-o, ao fim e ao cabo, a se defrontar com o dilema universal do nosso tempo: a renúncia da sua própria condição humana.

É nesse quadro distópico e parasitário que vimos sobressair o aumento exponencial do abismo entre os poucos indivíduos que têm e a imensa maioria 
daqueles indivíduos que nada possuem ${ }^{13}$. Com efeito, abandonando-se em meio à decadência que ele próprio criou, o indivíduo do presente faz e refaz os seus cálculos à maneira de um prestidigitador para manter a sensação de satisfação que ora assume a forma de uma fantasmagoria moral, ora a forma de uma fantasia narcísica. Subordinada sistemicamente ao valor, a vida social - sua economia, organizações jurídicas, religiosas, educacionais, artísticas, culturais etc. -, submete o indivíduo a um extraordinário processo de reificação contínua, seduzindo-o e pressionando-o esteticamente ao consumo espetacular explicitando na esfera cultural "o que ele é implicitamente na sua totalidade: a comunicação do incomunicável” (DEBORD, 2017, p. 149, grifo do autor).

Renunciando à fruição estética tout court, ou seja, ao valor de uso da arte e das demais relações com o mundo, o indivíduo revela o abandono da cultura como transcendência de si em face do mundo natural. Como pensava Lukács (1967), as realizações pseudoestéticas que integram o ciclo problemático do agradável constituinte da arte submetida à lógica do entretenimento, não produzem a capacidade de arrancar o indivíduo da mera singularidade, desenvolvendo nele o caráter social em contato com o gênero, transformando-o do em si, para si. Por fim, recuperando Marx (2004) ainda uma vez, há de se destacar que na medida mesma da consciência política que o indivíduo vier a desenvolver em todos os campos da vida social, incluindo o campo da arte, o salto transformador exigirá sempre uma tomada da consciência teorética sobre os sentidos humanos.

\section{Referências bibliográficas}

ALBINATI, Ana Selva. Lukács: A perspectiva ética no realismo crítico. In: VAISMAN, Ester; VEDDA, Miguel (Orgs.). Arte, filosofia e sociedade. São Paulo: Intermeios, 2014.

ANDERSON, Perry. Modernidade e revolução. Revista Novos Estudos, São Paulo, Cebrap, n. 14, pp. 2-15, 1985.

CHASIN, Ibaney. Música e mimesis: uma aproximação categorial e histórica ao pensamento musical. Verinotio - Revista on-line de Educação e Ciências Humanas, n. 9, ano V, nov. 2008. Disponível em: <http://www.verinotio.org/sistema/index.php/verinotio/article/view/252/2 40>, acessado em 13 fev. 2019.

DEBORD, Guy. A sociedade do espetáculo. Rio de Janeiro: Contraponto, 2017. EAGLETON, Terry. A ideologia da estética. Rio de Janeiro: Jorge Zahar Editor, 1993 .

13 Ver nota 9.

Elisabeth Soares da Rocha

Ronaldo Rosas Reis 
. A ideia de cultura. Rio de Janeiro: Jorge Zahar Editor, 2011.

FISCHER, Ernst. A necessidade da arte. 9. ed. Trad. Leandro Konder. Rio de Janeiro: Livros Técnicos e Científicos, 2014.

GABLER, Neal. Vida. O filme como o entretenimento conquistou a realidade. São Paulo: Companhia das Letras, 1999.

GRAMSCI, Antonio. Cadernos do cárcere v. 1. Trad. Carlos Nelson Coutinho. Rio de Janeiro: Civilização Brasileira, 1999.

- Cadernos do cárcere v. 2. Trad. Carlos Nelson Coutinho. Rio de

Janeiro: Civilização Brasileira, 2001.

HARVEY, David. Espaços de esperança. São Paulo: Edições Loyola, 2004. . Condição pós-moderna. Uma pesquisa sobre as origens da mudança cultural. São Paulo: Edições Loyola, 2014.

- 17 contradições e o fim do capitalismo. São Paulo: Boitempo Editorial, 2016.

JAMESON, Frederic. Pós-modernismo: a lógica cultural do capitalismo Tardio. São Paulo: Editora Ática, 1996.

LATOUCHE, Serge. A ocidentalização do mundo: ensaio sobre a significação, o alcance e os limites da uniformização planetária. Petrópolis: Vozes, 1996.

LUKÁCS, György. Ensaios sobre literatura. Coord. e prefácio Leandro Konder. Rio de Janeiro: Civilização Brasileira, 1965.

Estética v. 4. Trad. Manuel Sacristán. Barcelona/México, DF:

Ediciones Grijalbo, 1967.

. Realismo crítico hoje. Brasília: Coordenada Editora de Brasília, 1969.

. Prolegômenos para uma ontologia do ser social. Trad. Lya Luft e Rodnei Nascimento. São Paulo: Boitempo, 2010.

MARTINS, Luiz Renato. A arte entre o trabalho e o valor. Crítica Marxista Campinas/Rio de Janeiro, Cemarx/Revan, n. 20, pp. 123-38, 2005.

MARX, Karl; ENGELS, Friedrich. A ideologia alemã. São Paulo: Martins Fontes, 2002.

MARX, Karl. O capital. Rio de Janeiro: Bertrand, 2005.

. Manuscritos econômico-filosóficos. São Paulo: Boitempo, 2004.

OLDRINI, Guido. Em busca das raízes da ontologia (marxista) de Lukács. In: PINASSI, Maria Orlanda; LESSA, Sérgio (Orgs.). Lukács e a atualidade do marxismo. São Paulo: Boitempo, 2002.

REIS, Ronaldo Rosas. Trabalho e conhecimento estético. Trabalho, Educação e Saúde, Rio de Janeiro, EPJV/Fiocruz, v. 2, n. 2, pp. 227-250, 2004.

Ontologia crítica, estética e ética: um excerto. Revista Virtual EN-FIL, Niterói, Faculdade de Educação/UFF, ano 3, n. 5, 2015. Disponível em: <http://enfil.net/ed5/conteudo/index_o05_ronaldo.php>, acessado em: 13 mar. 2016.

REIS, Ronaldo Rosas; NOGUEIRA, Sonia Aparecida. Arte e promessa de liberdade: das contradições das vanguardas ao impasse da formação estético- 
cultural na atualidade. Revista Trabalho \& Educação, Belo Horizonte, Faculdade de Educação da UFMG, v. 24, n. 1, pp. 215-31, 2015.

SANTOS, Milton. Por uma outra globalização: do pensamento único à consciência universal. Rio de Janeiro/São Paulo: Record, 2012.

SEMERARO, Giovanni. Gramsci e os novos embates da filosofia da práxis. São Paulo: Ideias \& Letras, 2006.

SENNETT, Richard. A cultura do novo capitalismo. Rio de Janeiro: Record, 2006.

VAISMAN, Ester; FORTES, Ronaldo Vielmi. Apresentação. In: LUKÁCS, György. Prolegômenos para uma ontologia do ser social. São Paulo: Boitempo, 2010.

\section{Outras referências:}

BONG, Joon-Ho. Parasita (Gisaengchung). Filme, cor, 132 minutos. Coréia do Sul: Produtora Barunson E\&A Corp. Distribuidora CJ Entertainment, 2019.

Como citar:

ROCHA, Elisabeth Soares da; REIS, Ronaldo Rosas. A crítica da cultura e a educação estética. Verinotio - Revista on-line de Fỉosofia e Ciências Humanas, Rio das Ostras, v. 26, n. 1, pp. 16-43, jan./jun. 2020.

Data do envio: 6 fev. 2020

Data do aceite: 18 maio 2020 